ment of those results by using the relevant research community's own judgements of scientific value, both directly (through confidential questionnaires) and indirectly (through publication rates and citation frequencies).

A preliminary version of the radioastronomy study was read last year at a closed session of the Organization for Economic Cooperation and Development, and was very well received; but the wide circulation of that paper, particularly in the Netherlands and West Germany, whose own radio telescopes were also assessed (not all favourably) led to recrimination from Jodrell Bank, which did not do so well in the study. And now North-Holland, the publisher of Research Policy, in which the final paper was to appear, is said to be refusing to publish the radioastronomy work.

Moreover, the originator of the SPRU study, Sussex physicist Dr Norman Dombey, wishes to have no part in such publication, and says he disagrees completely with the work, mostly done by Martin and Irvine, and its conclusions. Dombey, although a high energy physicist, will not be a member of the group for its study of CERN, and argued with the Social Science Research Council that the CERN work should not be funded. However, after nearly a year's deliberations, the council has given the group a grant for 15 months' work on CERN and its future project LEP, but has insisted this time on extremely strict rules on confidentiality.

Robert Walgate

\section{Indian government policy Committed to science}

\section{New Delhi}

The poor coordination between Indian scientists and politicians should improve following long-awaited decisions announced by Mrs Gandhi recently. Mrs Gandhi herself is to preside over a ninemember Cabinet Committee on Science and Technology, dealing with broad policy matters, and two more science committees have also been formed.

India's worsening position on the energy front and a massive bill for oil imports have led to the formation of a six-member Alternative Energy Commission, along the lines of the Atomic Energy Commission, to be chaired by Professor M. G. K. Menon, Secretary of the Department of Science and Technology. The third committee, the Science Advisory Committee to the Cabinet, consists of 20 eminent Indian scientists from all the major disciplines. $\mathrm{Dr}$ M. S. Swaminathan heads this body which is to advise the cabinet on science and technology policy.

The Cabinet Committee on Science and Technology will have an important role in deciding how to spend the science and technology budget of more than 30,000 million rupees ( $£ 1,667$ million) allotted in

\section{Arnold at Christie's}

An 8-day marine timekeeper which is being offered for sale on 3 June at Christie's London auction rooms is thought to be a prototype for the modern marine chronometer, and it has been suggested that the spring detent which it employs could be the earliest ever, predating the putative "Earnshaw" pattern by several years. Made by John Arnold in London around 1775, the design of this un-numbered chronometer throws light on the many problems which confronted Arnold in his efforts to construct a timekeeper which would be accurate and reliable and could also be made in quantity at a relatively low price.

His chronometer (a term he himself coined) was designed to keep the same rate of going in every position and it incorporates a mechanism to compensate for changes in temperature. It has a threearmed uncut brass balance $\mathbf{4 5 . 2} \mathrm{mm}$ in diameter. Regulation is by flat spiral balance spring, regulated by curb pins carried on a bi-metallic compensation curb, concentric with the balance pivot. The convex enamelled dial bears the signature "Arnold, London". His earliest dials were enamelled, but once commercial production was started, he changed over to silvered dials. The box, $61 / 2$ inches square and $31 / 2$ inches deep, is of mahogany.

Arnold first started working on marine timekeepers in 1786, about nine years after John Harrison - the carpenter turned clockmaker - had submitted his No.4 timekeeper to the Board of Longitude. This was a body which had been set up by the British government and which in 1714 offered a prize of $£ 20,000$ for a machine which would enable longitude at sea to be determined to a specified degree of accuracy. Harrison richly deserved the prize but the board shillyshallied for many years, and it was only towards the end of his life that he recieved the final instalment of the award.

the country's sixth five-year development plan. Main areas of interest will be in life sciences, oceanography, alternative energy sources and bioengineering as applied to pharmaceuticals.

Naresh Sahajpal

- Energy alternatives: The Indian government has given fresh impetus to the development of new and renewable sources of energy. The key point of the plan is reduced dependence on imported oil. The government is investing in systems for utilization of energy from the Sun, wind and biomass.

In photovoltaics, the public sector company, Central Electronics Limited (CEL) of Sahibabad, has begun benchscale manufacture of single crystal silicon solar cells and panels with capacities of up to $10 \mathrm{~kW}$ per year. Solar modules developed by CEL are already being used in

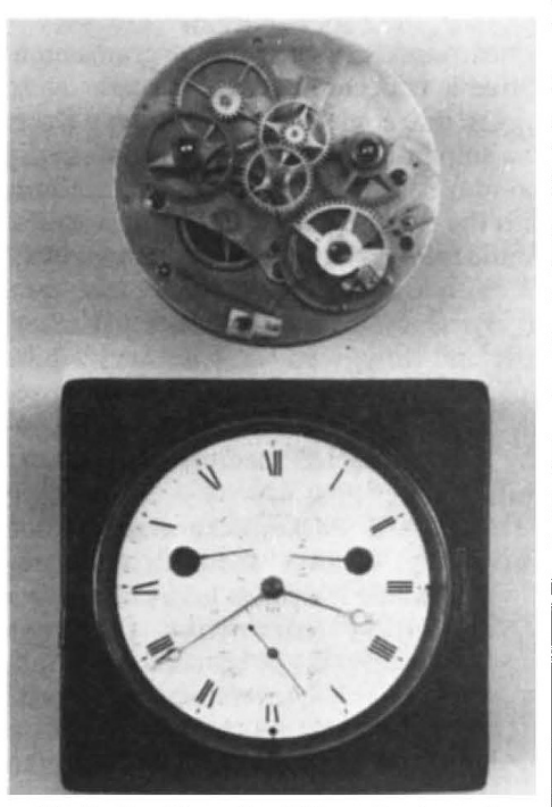

Had the Board of Longitude a free choice between the Harrison and Arnold timekeepers, the Arnold might well have been chosen on the grounds that it was less complicated and consequently easier to produce. Arnold made chronometers for the Admiralty at 60 guineas a piece, much cheaper than Harrison's which took about 3 years to make.

Arnold deserves much of the credit for introducing into England the manufacture of chronometers on a large scale.

As for the price likely to be reached when the chronometer is auctioned, Christie's are not willing to speculate. But if the device's history can be authenticated it could fetch anything between $£ 20,000$ and $£ 100,000$. Arthur Frank

Mr Arthur Frank, the now-retired owner of a Glasgow-based optical business, is a well known collector of optical and scientific instruments. Much of his collection, which includes early telescopes, cameras and eyeglasses, is now distributed among several British museums. Mr Frank will be contributing occasional articles when important scientific instruments change hands or come onto the auction markets.

powering a light beacon at Dwarka port, pumping water for a whole village in Rajasthan and lighting a 20-bed hospital in Ladhak. Solar water heating systems are being installed in many hotels, and a textile mill in Ahmedabad is already meeting its hot water requirements through a large solar heater.

A 120 million rupee ( $£ 7$ million) project has been drawn up for developing low cost solar-grade silicon material and cheap fabrication techniques and for improving the efficacy of solar cells and solar panels.

A national wind energy centre is being set up at Allahabad Polytechnic to develop a low-cost windmill. A cold storage plant utilizing geothermal energy is being set up in Himachal Pradesh. And a $600 \mathrm{MW}$ tidal power station is planned in the Gulf of Kutch in Gujarat.

Zaka Imam 